\title{
The Strategy of Fighting for the Telecommunications Fraud with International Police Cooperation
}

\author{
Aijiao Liu \\ Department of Technology, Yunnan Police College, Yunnan Kunming, China, 650223 \\ 18459423@qq.com
}

Keywords: Telecommunications fraud; Crime; International criminal police cooperation

\begin{abstract}
The international criminal police cooperation in the activities of investigation involves each link of the criminal investigation with the features that the telecommunications fraud is getting increasingly harmful, in which the scattered transnational crime dominated by individual or small group is just unfolding, The escapements and transferring of money among various countries are on the increase and Internet technologies are used for the implementation of transnational crime. Furthermore, telecommunications fraud is influenced by the factors such as diplomatic relations, the legal system and the investigation ability. The international criminal police cooperation in telecommunications fraud includes the exchanging of the case clues, criminal intelligence, assisting the investigation and evidence collection, it also contains the extradition, repatriation and recovering the proceeds of crime etc.
\end{abstract}

\section{Introduction}

Telecommunications fraud is referred to as the criminal behaviors that criminals fabricate false information and set traps to implement a remote and non-contact fraud to the victim, inducing him or her to pay or to transfer money into them in the form of the telephones, networks or other text messages as well as the purpose of the illegal possessions. The aspects of the telecommunication fraud are included as follows

The outstanding performance of telecommunication frauds are transnational crimes in the area of globalization.

The transnational crimes are featured with a new development in now global integration and they have become a prominent global issues. One of them is telecommunications fraud. The difference of the telecommunication fraud international criminal police cooperation with other international criminal police criminal cooperation lies on the feature of telecommunications fraud themselves.

The harm of telecommunications fraud transnational organized crime to human society is becoming more and more serious.

The provision of Article 1 of The United Nations Convention against Transnational Organized Crime: 'Organized criminal group' is a structured group of three or more persons, existing for a periods of time and acting in concerting with the aim of committing one or more serious crimes or offences established in accordance with this Convention to directly or indirectly get money or other material benefits. It can be seen from history that transnational organized crime is just the extension and development of domestic organized crime. Since entering the global integration, telecommunications fraud transnational organized crime is increasingly organized, the symbiotic crimes are increasingly more, the means of crime are increasingly various and the harms caused are increasingly serious as well. 1. Increasingly organized: The organization is the essential characteristic of organized crime [1]. In today's global integration, since each country has eased the exit and entry control, and the rapid development of international traffic, communication and information technology has facilitated the exchanges between countries, it is getting easier for a telecommunications fraud transnational organized crime group to control the standard to select its members. 2 . Increasingly more symbiotic crimes:' In the criminal law and criminology field, symbiosis is a very common phenomenon. The phenomenon of crime symbiosis forms a symbiotic mode between the units and in accordance with 
certain relationship and need, producing the symbiosis energy and promoting the common crimes [2]. It means having increasingly prominent technical features:' on one hand the development of science and technology has brought about more convenience for people's work, study and life. On the other hand it has also provided a transnational organized crime group with more high-tech means to commit a crime. As a result, transnational organized crime has undergone a thorough change, which is meaningless.' Transnational financial crime, especially transnational telecommunications fraud, is getting increasingly prominent. Since transnational telecommunications fraud can more effectively conceal and hide the proceeds of crime, it tends to evade the legal sanctions by intertwining with other transnational organized crimes.

Telecommunications fraud transnational organized crime, which is a scattered transnational on-the-run criminal offence dominated by individual or small group, is in the ascendant

Transnational on-the-run criminal offence is a spillover of domestic on-the-run criminal offence. Under the comprehensive action of the present negative effect, domestic on-the-run criminal offence will not disappear but spill over to the international community and become transnational on-the-run crime. The formation and development of the global market have made the person, money, material and information flow all over the world and under such environment a broader flowing space has been unavoidably provided for telecommunications fraud, so the trend of internationalization of telecommunications fraud is more and more prominent. Furthermore, traffic, communication and computer network globalization has also provided many technical facilities for telecommunications fraud transnational on-the-run crime. The global market mechanism has enlarged profit driven nature of commodity economy, which makes the greed of human nature expand in space.

It is increasingly rampant that criminals of telecommunications fraud transnational organized crime abscond and transfer their ill-gotten money between countries

Economic globalization does not lead to the integration of criminal justice. As for the current 'fit' paradigm of international police cooperation, its cooperative state and degree do not meet the current and future requirements of the global community and regional society to jointly and effectively combat international crime, strengthen the international protection of human rights and build a harmonious world. They are not conducive to the safety, stability and development of a modern state either. Furthermore, the novel 'and' paradigm of international criminal police cooperation - international policing integration is not mature yet [3]. 'An uncontrollable illegal private bank is surging an undercurrent for illegal cash transferring and rinsing [4].

Telecommunications fraud transnational organized crime and international Internet technical transnational crime have become a reality and trend

Transnational cybercrime is a crime associated with and accompanied by the development of the Internet. Telecommunications fraud belongs to transnational cybercrime. Now all the information can be uploaded and spread all over the globe on the Internet without any obstacle. It is a 'borderless, no police, no competent authority' international space, so many telecommunications fraud criminals are committing all kinds of telecommunications frauds by using this sort of 'state of anarchy [5].

\section{Obstacle for Telecommunications Fraud International Police Cooperation}

The international police cooperation against telecommunications fraud in the first decade of the 21st century has the problems of many points but less surface, not-in-depth information exchange, not-specific case cooperation, frequent cooperation and exchange but without mechanism, more agreements but less action, unequal tactical and strategic layout, etc. The main obstacles to the international police cooperation against telecommunications fraud are the change of diplomatic relations and the differences in legal system and investigation ability.

Analysis of the change of diplomatic relations on the international police cooperation against telecommunications fraud

International criminal police cooperation relies mainly on the cooperative willingness and enthusiasm of each country. This cooperation is not only from the police point of view, but also from 
the consideration of politics, economy, culture, etc. The international police cooperation against telecommunications fraud may involve several countries simultaneously. The process of police cooperation in some countries that have good diplomatic relations with our country will be smoothly carried out to timely find out the case and arrest the criminal suspects, while the process of police cooperation in some countries that have tense relations with our country will be beset with difficulties and such phenomenon may even occur that criminal suspects might be still unpunished without complete and timely evidence.

Legal analysis on the international police cooperation against telecommunications fraud

Since international criminal police cooperation must be carried out in the country within the scope of the law either in entity or procedure, it is not easy for each country to obtain a sweeping agreement on identification of some crimes due to the obstacle out of differences in national legal basis. Telecommunications fraud is a natural crime that is considered to constitute a crime in different legal regimes. Normally each country can follow the double crime principle to recognize it.

Analysis on the difference of investigation ability in telecommunications fraud international criminal police cooperation

Telecommunications fraud is a new type of intelligent crime for which many countries are still in the exploration and accumulation stage. Furthermore, this kind of crime investigation involves many searches and identifications of electronic evidence, so it is a huge challenge to the evidence system and technical investigation [6]. Due to the influencing factors such as economy, science and technology development, there is a big difference in the evidence standard and investigation ability to fight against telecommunications fraud between countries. In order to reduce the obstacles in cooperation, some training can be carried out to the investigators and the seminars or technical exchanges on telecommunications fraud can be held between countries.

\section{Countermeasures in Telecommunications Fraud International Criminal Police Cooperation}

International Investigation Jurisdiction of Telecommunications Fraud. The internationalization of computer network has led to two issues on the international jurisdiction of transnational cybercrime. One of them is the vague behavior and result of transnational cybercrime. Second one is the conflict of jurisdiction. In order to effectively investigate increasingly rampant transnational crimes and prevent transnational criminals from escaping the legal sanctions, the criminal behavior, result, nationality and victim countries can not only carry out the investigation activities in accordance with the three basic principles of territorial jurisdiction, personal jurisdiction and protective jurisdiction as well as the 'who found who jurisdiction who sponsored' investigation theory, but also request the related countries to give assistance in investigation. If two or more than two countries have found the same transnational crime, these countries can have either independent jurisdiction and independent investigation or mutual jurisdiction and joint investigation through consultation.

Exchange of Case Clues and Criminal Intelligence. Exchange of the case clues is the basic content of international criminal police cooperation, which is determined by the transnational feature of telecommunications fraud. With the investigation deepened, timely communication of case progress, transfer of evidence material, etc. are needed mutually between the countries. No matter whether it is centralized joint investigation or cooperative joint investigation, more fully and more timely exchange of criminal intelligence is needed to jointly investigate and solve the case. Actively building a network cooperation platform is out of the realistic need on the basis of mutual benefit for each country and it shall be executed continuously. In a word, exchange of the case clues and criminal intelligence shall be always carried out throughout the international criminal police cooperation against telecommunications fraud.

Assistance in the Investigation and Collection of Evidence. Assistance in the investigation and collection of evidence means that the country with jurisdiction or the local police department sends the investigators to the foreign territory to jointly carry out the investigation activities with the investigators of the local police department to ascertain the international criminal facts. 
Entrusting Others to Find or Identify the Relevant Personnel and Goods Is a Main Part of the Task in the Case of Telecommunications Fraud. Entrust and investigate the informant to collect the testimony material. No matter where a telecommunications fraud criminal is committing a crime, no matter how he or she conceals and no matter how he or she understands anti-investigation measures, he or she must contact some people on some occasions, which gives a chance for the investigators to deeply understand the real situation of criminal case.

Entrust others to visit the victim and collect his or her statement. Since the victim who is directly infringed by the criminal act has more profound understanding of the case and hates such crime very much, usually he or she will actively assist the public security department ascertaining the criminal facts and the requesting party can inquire the victim with the assistance of another party.

Entrust others to get the material evidence and documentary evidence. In the formation of criminal evidence, because of the objective authenticity, the material evidence and documentary evidence are the main evidence that can physically exist and be obtained.

Entrusting others to search, seizure or freeze can not only obtain the evidence, but also recover the proceeds of crime and income. The executive search, seizure or freezing procedures for telecommunications fraud shall be carried out in accordance with the relatively strict rules.

Based on the general international treaty and international criminal police cooperation practice, sending the investigators to obtain the evidence must be made in accordance with the law of the requested country and the principle that the competent authority of the requested party is dominant and that the requesting country puts forward the clear and specific request.

Extradition and Repatriation. There are many ways and means to transfer the runaways, among which the most common is the extradition and repatriation. The most common way and means to transfer the runaways of telecommunications fraud is to repatriate them.

After joining the International Criminal Police Organization in 1984, China has launched a lot of extradition practices and diplomatic contracting activities with many countries. As of May 2013, China has concluded bilateral extradition treaties with 36 countries in the world. From the perspective of international practice, an extradition can be conducted in two forms - diplomatic and judicial ways. If there is an agreement, an extradition can be made according to the treaty. Otherwise, an extradition is usually determined by the requested country itself in accordance with the United Nations "Model Treaty on Extradition'.

From a legal point of view, the repatriation is mainly an administrative measure to deal with illegal immigrants. Repatriation system is a system by which the government of the destination country of illegal immigrants forcibly send the illegal immigrants without entry permit or with the extended detention back to the countries of origin [7]. Compared with extradition, repatriation is a very formal international cooperation with flexibility and less limitation. It includes the repatriation of illegal immigrants, refugees and criminal suspects. What is more, the important measures to combat transnational crimes include the implementation of the criminal judgment of a foreign court and the transfer of jurisdiction of criminal proceedings.

Recover the Proceeds of Crime. Now transnational crime is mostly related to economic interests. The main purpose of cross-border fraud is to obtain illegal property without any labor to maintain a luxurious and dissipated life. While taking necessary cooperative measures to prevent, dispose and pursue the international fugitives of transnational crime, the police authorities of various countries shall fundamentally curb the development and spread of transnational crime. Such fundamental approach is to persistently recover the illegal property obtained by them from illegal practice. Only by allowing them to lose the economic conditions for them to survive and continuously commit a crime can the economic losses to the nation, unit and individual be reduced. There are usually two legal means to recover the lost property. The victims of crime can put forward proposals and requests directly to the judicial organs of the country according to the law of the country where the property is located and recover the proceeds of crime through the judicial cooperation between countries. Nowadays, the way for the public security organs to internationally recover the proceeds of crime is expanded. The methods include urging the criminal suspect to automatically withdraw from the proceeds of crime by 
using foreign favorable factors, recovering the proceeds of crime through the simple return procedure of a foreign country, guiding and assisting the victim taking a civil lawsuit in the foreign country to recover the proceeds of crime and recovering the proceeds of crime through China court ruling.

\section{Conclusion}

A conclusion can be drawn from the above that telecommunications fraud is featured with higher organization, more symbiotic crimes, increasingly prominent technical means, etc. According to the principle and practice of international criminal police cooperation, the present paper has deeply studied the basic issues such as the contents and procedures of international criminal police cooperation in the investigation of telecommunications fraud, probing a more feasible and flexible international criminal police cooperation against telecommunications fraud, which also requires the police authorities of each country to work together with concerted efforts.

\section{References}

[1] Di Ying qi: Organized Crime and Its Characteristics, Journal of Henan Administrative Institute of Politics and Law, No. 4, 2002.

[2] Fei Xiao tong: Native China, Shanghai People's Publishing House (2006), P. 360.

[3] Jing Chang ling: Development logic and International Rationality of the International Policing Integration, Journal of Political Science and Law, No. 6, 2009.

[4] The Prospective of Our Country Absconding Corrupt Officials (novelette), Xinhuanet.com, August 20, 2002.

[5] Zhang Yu: The Internet and International Crime, Journal of Sichuan College of Education, No. 7, 2001.

[6] Yang $\mathrm{Yu}$ juan $\mathrm{On}$ the International Police Cooperation in the Investigation of Telecommunications Fraud, Journal of Guangzhou Police college, No. 1, 2013.

[7] Refer to http://www.iom.int, International Migration Law: Glossary on Migration, 2004. 